\title{
HIV-Associated Polyneuropathy in Resource-Limited Settings: Genetic Predisposition and Vitamin Variations
}

\author{
Frank N. Ndakala1,2, Julius 0. Oyugi², Margaret 0. Oluka ${ }^{3}$ \\ ${ }^{1}$ Directorate of Research Management and Development, State Department of Science and Technology, Nairobi, Kenya \\ ${ }^{2}$ Institute of Tropical Infectious Diseases (UNITID), University of Nairobi, Nairobi, Kenya \\ ${ }^{3}$ Department of Pharmacology and Pharmacognosy, University of Nairobi, Nairobi, Kenya \\ Email: fsawanga@gmail.com
}

How to cite this paper: Ndakala, F.N., Oyugi, J.O. and Oluka, M.O. (2017) HIVAssociated Polyneuropathy in ResourceLimited Settings: Genetic Predisposition and Vitamin Variations. World Journal of AIDS, 7, 106-121.

https://doi.org/10.4236/wja.2017.72010

Received: June 7, 2015

Accepted: June 18, 2017

Published: June 21, 2017

Copyright $\odot 2017$ by authors and Scientific Research Publishing Inc. This work is licensed under the Creative Commons Attribution International License (CC BY 4.0).

http://creativecommons.org/licenses/by/4.0/

\begin{abstract}
Human immunodeficiency virus-related polyneuropathy remains a painful condition resulting from damaged nerve endings. HIV infection strongly associates with a predominantly polyneuropathy that is attributed to HIV infection itself, or a toxic neuropathy associated with combination antiretroviral therapy (CART). In non-HIV-infected individuals, both deficiency and high intake of vitamins have been associated with polyneuropathy. For that reason, clinicians recommend vitamin supplements before and during CART. Although some, but not all, HIV-related vitamin deficiencies may replete during treatment with CART, it is predictable that high vitamin supplement intakes may contribute to nerve disorders. In resource-limited settings where the diagnosis of polyneuropathy heavily relies on symptoms, data on risk factors for polyneuropathy including vitamin status, alcohol consumption, and co-infections are limited. In addition, studies on genetic influence on the concentration of micronutrients in the blood of long-term users of CART are scarce. Possible sources of high intakes of vitamins could arise from the fact that a number of HIV-infected persons self-medicate. In addition, since HIV-infected individuals have an increased lifespan, relying on symptoms alone to specifically diagnose HIV-associated neuropathies could be a barrier to effective treatment in recourse-poor settings. This paper reviews evidence on single nucleotide polymorphisms (SNPs) with the potential to influence bioavailability of vitamins in HIV-infected patients. Genome-wide association studies have reported SNPs in alkaline phosphatase, fucosyltransferase 2, cubilin, transcobalamin 1, and tumor necrosis factor as potential determinants of various blood levels of vitamin B-6, B-12 and E. As long term CART increasingly become, personalized, future research should focus on SNPs, which influence vitamin blood levels, and with potential to augment long-term treatment with CART.
\end{abstract}




\section{Keywords}

Human Immunodeficiency Virus, Combination Antiretroviral Therapy, Single Nucleotide Polymorphisms and Polyneuropathy

\section{Introduction}

Vitamin deficiencies in HIV patients, strongly indicate a higher degree of disease progression [1], adverse effects and high mortality during the initiation of combination antiretroviral treatment (CART) [2] [3] [4]. Polyneuropathy (PN) has probably emerged as the most prevalent neurologic adverse outcome associated with human immunodeficiency virus (HIV) infection [5] [6], CART [7] and serum vitamin concentration.

$\mathrm{PN}$ remains difficult to treat and causes significant functional impairment that negatively affects the patient's quality of life [8]. Its symptoms include distal symmetrical distribution, sensorimotor paralysis, paresthesia and pain in the hands and feet. The pathogenesis of PN is likely multifactorial [9] with known risk factors such as treatment with nucleoside analogues, other neurotoxic drugs, vitamin B-12 deficiency, alcohol abuse, and diabetes mellitus. The HIV protein (gp120), as well as host chemokine and cytokine responses, may trigger a multifaceted interaction that leads to PN [6].

Prior to CART, the prevalence of PN was approximately $14 \%$ among outpatients. It ranged from $2 \%-35 \%$ depending on whether patients had early HIV disease or in the hospital [10] [11]. About 11\% - 43\% of CART naive individuals in most resource-limited settings present PN [12] [13] [14] [15]. The use of dideoxynucleoside reverse transcriptase inhibitors (dNRTIs) increases the risk of neurotoxicity [7]. As viral gp120 or HIV-associated chronic immune dysregulation may directly sensitise peripheral sensory nerves, dNRTI-induced mitochondrial toxicity could exacerbate the condition. Stavudine (d4T) is a notable dNRTIs that has strongly been associated with mitochondrial toxicity. Adverse effects associated with mitochondrial toxicity such as PN and lipodystrophy led to the discontinuation of $\mathrm{d} 4 \mathrm{~T}$ [16]. However, due to low cost and limited alternatives, $\mathrm{d} 4 \mathrm{~T}$ is still used resource-limited settings [17].

Chronic immune activation characterised by increased generation of free reactive oxygen species (ROS) and perturbation of antioxidant defence system has been shown to occur in HIV-infected patients [18] [19] [20]. This creates an oxidative stress (OS) which is instability between oxidants and antioxidants. This state damages both structure and function of key tissues [21]. As a cofactor, OS may enhance disease pathogenesis through increased viral replication, inflammatory responses and sensitivity to ARV-drugs [21]. Therefore, OS resulting from CART may be far much beyond levels of that caused by HIV disease itself. It is also associated with PN and can increase the body's demand for certain antioxidants such as vitamins.

Deficiencies in body micronutrients occur due to reduced intake of micronu- 
trients caused by to HIV infection associated anorexia, excessive micronutrient loss through the stool, malabsorption, increased metabolic demand, body redistribution and parasitic infections [22] [23] [24]. Vitamin deficiency in HIV-infected individuals may be high as a result of the abnormality [25] [26] [27] [28]. That explains the reason behind recommended daily doses of vitamin supplements as a measure of preventing PN before CART initiation. When a patient reports symptoms of PN during CART clinicians prescribe vitamin supplements as a way of treating this disorder.

In resource-limited settings, the HIV-infected population heavily rely on over the counter minerals, vitamins, phytotherapeutic preparations and alternative medicines without any substantiated scientific evidence to support their use [29]. Most patients feign ignorance when it comes to high intakes of vitamin products available to them [30] [31].

\section{Biochemical Functions of Vitamins}

The body needs several nutrients including flavoproteins and cytochromes for normal functioning of the mitochondria [32]. Micronutrient deficiencies predispose HIV-infected individuals to mitochondrial toxicity, a condition that leads to oxidative stress (OS). The impairment of the antioxidant defence system during OS involves an imbalance in redox status, which can cause a deficiency in micronutrients and contribute to disease progression. These reactions are linked to cellular apoptosis, PN and decreased immune proliferation [19] [20] [21]. The redox imbalance cover changes in glutathione (GSH), thioredoxin (TRX), superoxide dismutase (SOD), ascorbic acid, glutathione peroxidase (GPx), tocopherol (TOC) and selenium (Se).

Vitamins act as co-enzymes in the breakdown of food for energy production [33] [34] [35]. Deficiencies in vitamin A, B-1, B-2, B-6, B-12, and E can impair host resistance and lymphocyte function [34]. Vitamin A deficiency leads to impaired neutrophil function and reductions in lymphocyte response. The reduction in cell-mediated immune response may result from lack of vitamin C. Low vitamin $\mathrm{E}$ levels may cause interference in both proliferation and functions of T-cells [36] [37]. Antioxidants reduce the damage caused by OS [34]. Due to interrelated functions, thiamine, riboflavin, pyridoxine, cobalamin, niacin pantothenic acid, biotin and folic acid are available as a single formulation of vitamin $B$ complex [38]. The focus of this paper is on vitamins that have been associated with PN. They include vitamin B-1, B-6, B-12 and E (Table 1).

\subsection{Vitamin B-1 (Thiamine)}

Thiamine exists in five forms namely, thiamine monophosphate (ThMP), thiamine diphosphate (ThDP), also called thiamine pyrophosphate (TPP), thiamine triphosphate (ThTP), adenosine thiamine triphosphate (AThTP), and adenosine thiamine diphosphate (AThDP). The best-characterized form is TPP, a coenzyme in the catabolism of sugars and amino acids. Thiamine participates in thedecarboxylation of alpha-keto acids, branched-chain amino acids during energy 
Table 1. The main functions and deficiency states of selected vitamins.

\begin{tabular}{|c|c|c|}
\hline Vitamin & Main function & Main deficiency symptoms \\
\hline $\begin{array}{c}\text { Retinol } \\
(\text { Vitamin A) }\end{array}$ & $\begin{array}{l}\text { Maintain healthy surface linings of the eyes, the respiratory, } \\
\text { urinary, and intestinal tracts, the skin and mucous } \\
\text { membranes; night vision; bone development; antioxidant. }\end{array}$ & $\begin{array}{l}\text { Bitot's spots, xerophthalmia, corneal ulcers, } \\
\text { scarring of the cornea and blindness; impaired dark } \\
\text { adaptation. High incidence of respiratory } \\
\text { illnesses and diarrhoea; increased mortality }\end{array}$ \\
\hline $\begin{array}{c}\text { Thiamin } \\
\text { (Vitamin B-1) }\end{array}$ & $\begin{array}{l}\text { Carbohydrate metabolism, } \\
\text { coenzyme for synthesis of nucleic acids }\end{array}$ & $\begin{array}{l}\text { Polyneuropathy (PN), diminished sensation } \\
\text { and weakness in the extremities. Muscle pain } \\
\text { and tenderness, seizures (severe deficiency). } \\
\text { Signs of congestive heart failure }\end{array}$ \\
\hline $\begin{array}{c}\text { Niacin } \\
\text { (Vitamin B-3) }\end{array}$ & $\begin{array}{l}\text { Metabolism of carbohydrates, fats and proteins } \\
\text { and synthesis of fatty acids and cholesterol }\end{array}$ & $\begin{array}{l}\text { Dermatitis, diarrhoea, bright red tongue, } \\
\text { vomiting, and diarrhoea, apathy and fatigue }\end{array}$ \\
\hline $\begin{array}{c}\text { Pyridoxine } \\
\text { (Vitamin B-6) }\end{array}$ & $\begin{array}{l}\text { Coenzymes that catalyse gluconeogenesis, synthesis of } \\
\text { neurotransmitters, heme, nucleic acids, conversion of } \\
\text { homocysteine to cysteine, production of lymphocytes and IL-2 }\end{array}$ & $\begin{array}{l}\text { PN, irritability, confusion, seizures in severe deficiency. } \\
\text { Inflammation of the tongue, sores or ulcers } \\
\text { of the mouth, angular stomatitis and anaemia. }\end{array}$ \\
\hline $\begin{array}{c}\text { Folic acid } \\
(\text { Vitamin B-9) }\end{array}$ & $\begin{array}{l}\text { Metabolism of nucleic acids and amino acids, } \\
\text { synthesis of DNA, RNA, conversion } \\
\text { of homocysteine to methionine. }\end{array}$ & $\begin{array}{l}\text { Megaloblastic anaemia and symptoms of anaemia } \\
\text { (fatigue, weakness, and shortness of breath) }\end{array}$ \\
\hline $\begin{array}{c}\text { Cobalamin } \\
(\text { Vitamin B-12) }\end{array}$ & $\begin{array}{l}\text { Amino acid metabolism, methylation of a number of sites } \\
\text { in DNA and RNA, production of energy } \\
\text { from fats and proteins, haemoglobin synthesis. }\end{array}$ & $\begin{array}{l}\text { Megaloblastic anaemia, PN, difficulty walking, } \\
\text { mood changes, tongue soreness, } \\
\text { appetite loss, and constipation }\end{array}$ \\
\hline $\begin{array}{l}\text { Ascorbic acid } \\
\text { (Vitamin C) }\end{array}$ & $\begin{array}{l}\text { Synthesis of collagen, synthesis of carnitine } \\
\text { which is essential for thetransport of fat into mitochondria for } \\
\text { theproduction of energy, metabolism of cholesterol to bile acids. } \\
\text { Antioxidant, enhance chemotaxis and phagocytosis }\end{array}$ & $\begin{array}{l}\text { Bleeding and bruising easily hair and tooth loss, } \\
\text { and joint pain and swelling, fatigue }\end{array}$ \\
\hline $\begin{array}{l}\text { Cholecalciferol } \\
\text { Vitamin D) }\end{array}$ & $\begin{array}{l}\text { Absorption of calcium and hardening of bones. DNA synthesis } \\
\text { and transcription of genes, cellular differentiation, modulates } \\
\text { immune cells e.g. dendritic cells and macrophages }\end{array}$ & $\begin{array}{l}\text { Rickets, muscle weakness and pain, } \\
\text { frequent bacterial infections }\end{array}$ \\
\hline $\begin{array}{l}\text { Alphatocopherol } \\
\text { (Vitamin E) }\end{array}$ & $\begin{array}{l}\text { Antioxidant, maintain integrity of cell membranes, } \\
\text { affect the expression and activities of enzymes } \\
\text { in immune and inflammatory cells }\end{array}$ & PN and muscle weakness \\
\hline
\end{tabular}

Source: http://lpi.oregonstate.edu/mic/.

generation, biosynthesis of the neurotransmitter acetylcholine and gammaaminobutyric acid (GABA).

There are no reports of adverse effects associated with excessive consumption of thiamine [39]. Deficiency in thiamine from various sources [40] [41] may cause nerve disorders. The prognosis may then progresses to a condition called beriberi. Patients with dry beriberi show symptoms of PN [41] [42].

\subsection{Vitamin B-6 (Pyridoxine)}

Three forms of vitamin B-6 pyridoxine, pyridoxal and pyridoxamine are enzymatically interconvertible. The human body converts pyridoxine into pyridoxal phosphate (PLP) which is an essential co-factor in the removal of acarboxyl group, sulphurdioxide, anamino group and amino transfer. The phosphorylation of pyridoxine to PLP is via ATP-dependent pyridoxal phosphokinase. PLP and pyridoxal are the main circulating forms found in most animal tissues [26]. Vi- 
tamin B-6 is unique in that either a deficiency or an excess can cause PN. High intakes of vitamin B-6 can cause deleterious effects [43] [44].

Although vitamin B-6 deficiency occurs among HIV-infected, it also occurs in patients treated with isoniazid, phenelzine, hydralazine, and penicillamine [43]. Among other things, deficiency of vitamin B-6 causes neurological effects such as seizures and convulsions. There is evidence that in HIV-infected people, lack of vitamin B-6 impairs the immune cell functions, through the reduction of lymphocyte maturation and diminished antibody production [45].

\subsection{Vitamin B-12 (Cobalamin)}

Cobalamin participates in the formation of methionine by methylation of homocysteine [43]. The resultant byproduct tetrahydrofolate is useful in synthesising purine and pyrimidine. In addition, the formation of myelin sheath depends on cobalamin's participation in the conversion of l-methylmalonyl coenzyme A into succinyl coenzyme A.

The classical neurological effects of vitamin B-12 deficiency include sub-acute combined degeneration, neuropsychiatric symptoms, $\mathrm{PN}$ and optic neuropathy. The most common cause of cobalamin deficiency is pernicious anaemia, a condition more common in African-Americans and Northern Europeans [43].

\subsection{Vitamin E (Alpha-Tocopherol)}

Vitamin E consists of similar chromanol structures; trimethyl (a-), dimethyl (bor g-), and monomethyl (d-) tocopherol, and the corresponding tocotrienols [46]. The most abundant form of vitamin $\mathrm{E}$ in human beings is alpha-Tocopherol. Vitamin E inhibits lipid peroxidation in cell membranes and prevents OS. The transfer of vitamin E to very low-density lipoproteins (VLDL) takes place via alpha-tocopherol transfer protein (TTP) [26] [47].

Since adipose tissues naturally contain alpha-tocopherol, its deficiency may take years to detect. Specifically, lack of vitamin E impairs T cell-mediated function, lymphocyte proliferation [48] and the principal pathological features include PN [27].

\subsection{Lows and Highs of Vitamin Supplements for HIV-Infected Patients}

As Renwick [44] proposed that very low intakes of micronutrients would present adverse effects, which would decrease in severity with an increase in intake, and that severity of toxicity at high intakes will increase with dosage (Figure 1).

That implies, safe usage of vitamin supplements in food insecure settings requires careful consideration of previous studies on large doses of micronutrients [49], the upper tolerable levels (ULs) of intakes and potential adverse effects. The highest level of consumption where the risk of toxicity is equivalent to zero as defined by UL (Figure 1) [44]. To demonstrate meeting the need for a nutrient, the EAR characterizes the intake level of a nutrient at which the need of $50 \%$ of the population in that age group and gender. Lastly, recommended daily allow- 


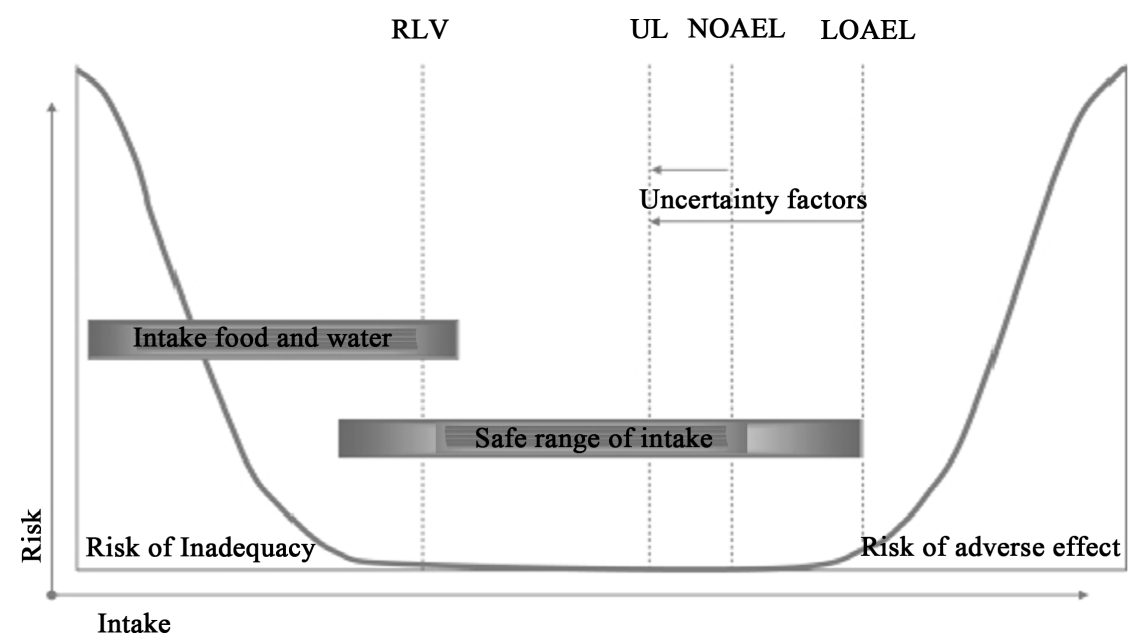

Figure 1. Theoretical description of the risk of developing adverse effects at various levels of micronutrient intake. Abbreviations: EAR-estimated average requirements (mean/ median requirement of the population); RLV—reference labelling values (RDA-recommended daily allowance: the intake that meets the needs of $97 \%-98 \%$ of healthy individuals in a population); UL-tolerable upper intake level; NOAEL-no observed adverse effect level; LOAEL-lowest observed adverse effect level; UL_tolerable upper intake level. Source: Renwick (2006) [44].

ance (RDA) is the daily dietary intake level of a nutrient considered sufficient to meet the requirements of nearly all (97\% - 98\%) the healthy individuals in each life-stage and gender group. The relative position of the two curves may vary widely between different vitamins and minerals.

The RDA for thiamine ranges from $1.0-1.5 \mathrm{mg}$ per day for young adults and breastfeeding mothers respectively [47]. The human body excretes thiamine principally in the urine [50]. So far, there are no reports of thiamine toxicity related to dietary intakes.

Doses of $>200 \mathrm{mg}$ daily of vitamin B-6, which can occur during supplementation, were associated with $\mathrm{PN}$, uncoordinated movement, breathing difficulties, fatigue, and vomiting. Vitamin B-6 toxicity produces a sensory ataxia, are flexia, and impaired cutaneous sensation. Patients often complain of burning or paresthesia. The RDA for pyridoxine is $1.3 \mathrm{mg}$ daily with the upper limit (UL) of 100 mg daily for all adults. There is evidence that symptoms of toxicity can occur with doses as low as $100 \mathrm{mg}$ per day [51]. That explains why supplementation guidelines do not recommend doses of $50 \mathrm{mg}$ to $100 \mathrm{mg}$ of vitamin B-6 [52]. Subjects using doses of up to and exceeding $1 \mathrm{~g} / \mathrm{d}$ of pyridoxine showed symptoms of neurotoxicity. In addition, subjects who had chronic high intakes of 1-6 g/d oral pyridoxine developed symptoms of PN [52] [53].

About $40 \%$ older adults have low serum vitamin B-12 levels, 5\% - 20\% of which experience vitamin B-12 deficiency. The RDA for vitamin B-12 is $2.4 \mathrm{mcg}$ daily [47] [54], where pregnant and lactating women should take $2.6 \mu \mathrm{g}$ and 2.8 $\mu \mathrm{g}$ per day respectively. Vitamin B-12 remains safe when used orally in amounts that do not exceed RDA. However, studies have shown no adverse consequences of doses above the RDA. 
High UL of $1000 \mathrm{mg}$ per day of vitamin E have been established, however, due findings from meta-analyses the RDA remains 15 - $20 \mathrm{mg}$ per day of alpha-to copherol [55]. From the same meta-analyses, low-dose intakes of $150 \mathrm{mg}$ per day proved beneficial. However, high intakes can indeed cause harm. Vitamin E may damage cells by acting as a pro-oxidant, hence causing oxidation [56].

Unlike deficiencies, vitamin toxicities in HIV-infected patients in many resource-poor settings are scarce. The available data is inconsistent, scanty and largely based on individuals who are not HIV-infected. The data do not clearly support vitamin toxicity as a problem to be cautious about in HIV-infected persons. This, therefore, suggests that even with HIV-related PN, vitamin toxicity resulting from high intakes of supplements is less likely to be significant.

\subsection{Effects of HIV-Infection on Vitamin Levels}

Through malabsorption and rapid nutrient utilisation, HIV infection directly leads to the decline in CD4 cells and micronutrient levels (Figure 2) [57] [58]. In turn, the level of essential nutrients like vitamin $\mathrm{E}$ is affected [59]. HIV-infection has also been associated with increased basal metabolic rate, increased energy expenditure and protein catabolism [60]. Further, the reduction in serum concentration of vitamins B6, B12 and E usually associated with low CD4 cells [56] [61], increases both OS and vitamin A, C and E uptake [62] [63].

\subsection{Effect of CART on Vitamin Levels}

Patients who use current classes of CART drugs that include reverse transcriptase inhibitors (NRTIs) or non-nucleoside reverse transcriptase inhibitors (NNRTIs) [64] [65], may experience lactic acidosis, hepatic steatosis (fatty liver), lipodystrophy and PN [66]. Metabolic adverse effects directly or indirectly affect the serum level of micronutrients.

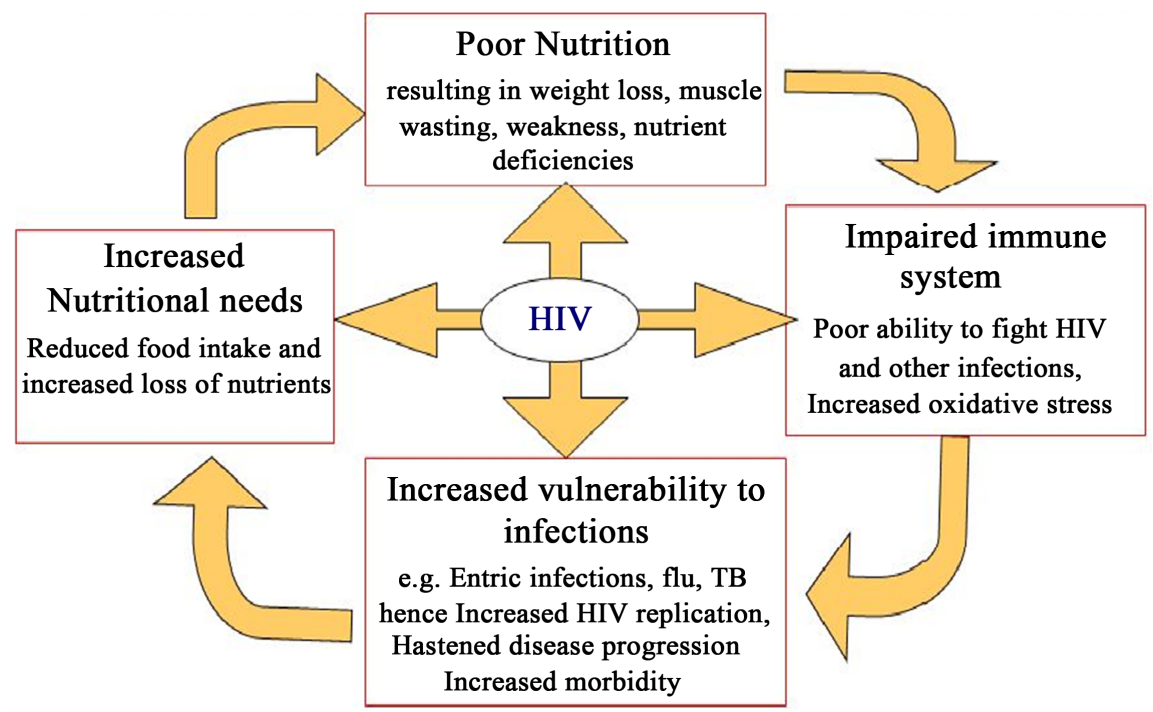

Figure 2. 'The vicious cycle of malnutrition and HIV' (Source: http://motherchildnutrition.org/nutrition-hiv-aids/nutrition-living-with-hiv-aids/cycle-o f-malnutrition-and-hiv-aids.html). 
NRTIs cause mitochondrial damage, which not only leads to perturbation in the structure of mitochondria but also depletion of mitochondria. Accumulation of damaged mitochondria (mitochondrial toxicity) can reduce the absorption or increase the losses of several nutrients through vomiting and diarrhea [67]. Mitochondrial toxicity may also increase the production of ROS hence increasing the demand for antioxidant micronutrients. That explains why vitamin supplementation of lost vitamins reduces some complications related to the use CART.

The use of zidovudine (ZDV) was associated with low serum concentration of vitamin B-12 [68] [69]. Clinicians prescribe vitamin B-12 for treatment of ZDVassociated haematological toxicity and anaemia, which affects approximately $5 \%-10 \%$ of HIV-infected patients [68] [69]. Vitamin B-1 and vitaminB-2 which play a key role in the normal functioning of mitochondria, have both been found to diminish the effect of NRTI-associated lactic acidosis [70] [71]. CART related abnormal fat distribution, dyslipidemia and insulin resistance resulting from ROS can be minimised by vitamin E intakes [72]. Patients using a combination of 10 micronutrients reported a significant reduction in theincidence of PN [73].

\subsection{Genetic Predisposition}

Susceptibility to PN varies among HIV-infected persons, with prevalence rates reported to range from $10 \%-35 \%$ [74]. The variability suggests a role for human genomic variation, though with much focus on mitochondrial DNA (mtDNA) variations. A number of mitochondrial haplogroups have been associated increased risk of mitochondrial dysfunction. People with European descent belonging to mitochondrial haplogroup $\mathrm{T}$ showed a marginally higher incidence of NRTI-associated neuropathy [75]. Hulgan and colleagues performed a mitochondrial haplogroup $\mathrm{T}$ demonstration in a CART exposed Caucasian casecontrol cohort. From their findings, about $17 \%$ of individuals who developed PN had mtDNA haplogroup T compared to 7\% who did not develop PN [75]. African mtDNA generally have greater variation than that of Caucasians and thus difficult to classify. There exist limited association studies on African mtDNA variation. A single study on a non-Hispanic, African American cohort, identified mtDNA sub-haplogroup L1c as an independent predictor of PN [76]. Since the causes of PN are multifactorial, it is important to examine other genetic variations, which may explain susceptibility to PN, especially those affecting serum vitamin concentrations.

Evidence show that the amount of vitamin B and homocysteine circulating in the blood is genetically determined [77]. The 677T $\leftarrow \mathrm{C}$ ( $\mathrm{rs} 1801133)$ polymorphism in exon 5 of the 5,10 -methylenetetrahydrofolate reductase (MTHFR [MIM 607093]) gene is responsible for the level of vitamin B and homocysteine in the blood. Poor conversion of 5, 10-methylenetetrahydrofolate to 5-methyltetrahydrofolate is a consequence of phenotype in a thermolabile enzyme produced by a phenotype of the $677 \mathrm{~T}$ variant [78]. Individuals with such phenotype have higher homocysteine concentration, lower genomic DNA methylation [79] 
and may experience vitamin deficiency [80]. The concentration of vitamin B and homocysteine associates with other genetic variations, although results remain inconsistent [81].

Mutations in the alkaline phosphatase $(A L P)$ gene characterised by the low or complete absence of $A L P$ activity, manifest as hypophosphatasia. This is an accumulation of phosphorous compounds including vitamin B-6 [82]. The concentration of vitamin B-6 was associated with the top signal namely rs1780324 polymorphism found within the $A L P$ gene region [83]. In the presence of allele C, polymorphism, rs4654748 has most significantly been associated with vitamin B-6 deficiency. One study suggested that ALP mediates the association between two ALP gene SNPs (rs4654748 and rs1780324) with vitamin B-6 [83]. Since ALP enzyme plays a role in clearing vitamin B-6, lower vitamin B-6 levels in C allele carriers' could result from efficient clearance of vitamin B-6.

Studies have associated deficiency in vitamin B-12 with the overgrowth of $\mathrm{He}$ licobacter pylori [84]. The $\mathrm{H}$-antigens participate in mediating adhesion of $H$. pylori to gut mucosa.The fucosyltransferase 2 (FUT2) gene determines the human secretor (Se) blood group through $\alpha 1,2$-fucosyltransferase phenotype expression. FUT mediates the fucosylation of oligosaccharides to form H-type 1 and 2 antigens [85]. Researchers have mapped rs6022662 SNP to exon 2 of the FUT2 gene, in which the presence of the A allele was associated with higher vitamin B-12 concentrations [86]. In the Portuguese population, one study identified the rs6022662 SNP in individuals with non-secretor status, or the absence of $\mathrm{H}$ antigen [87]. This suggested that higher vitamin B-12 status in A allele carriers may result from a reduction in the susceptibility to bacterial infection and indirect reduction of the vitamin B-12 malabsorption associated with FUT2 enzyme in A allele carriers.

Other SNPs may be associated with the level of vitamin B-12 include rs11254363 and rs526934, located in intron 52 of the intrinsic factor-cobalamin receptor, cubilin (CUBN [MIM 602997]) gene and in intron 8 of the transcobalamin 1 (TCN1 [MIM 189905]) gene respectively. Mutations in CUBN cause megaloblastic anaemia 1 (MGA [OMIM 261100]), characterised by juvenile pernicious anaemia [88] [89]. Mutations in TCN1 cause deficiency in transcobalamin 1 (OMIM 193090), often found in patients with low vitamin B-12.

Vitamin $\mathrm{E}$ has been shown to have an immunomodulatory effect, which in part is mediated via its effects on the production of interleukin (IL)- $1 \beta$, tumour necrosis factor (TNF)- $\alpha$, and IL-6 [90]. SNPs located in IL-1 $\beta$, IL-6 and TNF- $\alpha$ genes have been associated with cytokine production [91]. Genotypes AA and A/G located at TNF- $\alpha-308 \mathrm{G}>\mathrm{A}$ were reported in subjects treated with vitamin $\mathrm{E}$ and had lower TNF- $\alpha$ production than placebo. In a genome-wide association study of circulating $\alpha$-tocopherol, Major et al., (2012) [91], identified SNPs rs964184 on 11q23.3 $\left(P=2.6 \times 10^{-12}\right)$, rs2108622 on 19pter-p13.11 $(P=2.2 \times$ $\left.10^{-7}\right)$ and rs7834588 on $8 \mathrm{q} 12.3\left(P=6.2 \times 10^{-7}\right)$. In total, the three SNPs represent $3.4 \%$ of the residual variance that may be associated with the serum concentration of $\alpha$-tocopherol during vitamin E supplementation. 


\section{Conclusion}

In conclusion, the diagnosis of PN heavily relies on clinical symptoms in many resource-limited settings. To manage this condition clinicians prescribe vitamin supplements because they are easy and inexpensive adjunctive therapy for improving HIV medication outcome. However, since there is poor screening of risk factors of PN and that patients can easily get affordable vitamins over the counter, the development of PN remains a big burden in these settings. Although the benefits of vitamin supplements in CART naive individuals are well established, there need for studies focusing on how SNPs could influence levels of vitamins in HIV-infected patients receiving CART. As the HIV care rapidly advances towards personalised therapy, the application of micronutrient associated commonly, distributed SNPs among ethnic groups in resource-poor settings would greatly improve long-term treatment outcomes of HIV-infected persons.

\section{Acknowledgements}

The authors acknowledge the International Infectious Diseases and Global Health Training Programme (IID\&GHTP), Manitoba, Canada for facilitating the review.

\section{References}

[1] Kupka, R., Msamanga, G.I., Spiegelman, D., et al. (2004) Selenium Status Is Associated with Accelerated HIV Disease Progression among HIV-1-Infected Pregnant Women in Tanzania. Journal of Nutrition, 134, 2556-2560.

[2] Lawn, S.D., Harries, A.D., Anglaret, X., Myer, L. and Wood, R. (2008) Early Mortality among Adults Accessing Antiretroviral Treatment Programmes in Sub-Saharan Africa. AIDS, 22, 1897-1908. https://doi.org/10.1097/QAD.0b013e32830007cd

[3] May, M., Boulle, A., Phiri, S., et al. (2010) Prognosis of Patients with HIV-1 Infection Starting Antiretroviral Therapy in Sub-Saharan Africa: A Collaborative Analysis of Scale-Up Programmes. Lancet, 376, 449-457. https://doi.org/10.1016/S0140-6736(10)60666-6

[4] Zachariah, R., Harries, K., Moses, M., et al. (2009) Very Early Mortality in Patients Starting Antiretroviral Treatment at Primary Health Centres in Rural Malawi. Tropical Medicine \& International Health, 14, 713-721. https://doi.org/10.1111/j.1365-3156.2009.02291.x

[5] Tagliati, M., Grinnell, J., Godbold, J. and Simpson, D.M. (1999) Peripheral Nerve Function in HIV Infection: Clinical, Electrophysi-Ologic, and Laboratory Findings. Archives of Neurology, 56, 84-89. https://doi.org/10.1001/archneur.56.1.84

[6] Van der Watt, J.J. (2013) HIV-Associated Sensory Neuropathy in an African Cohort; a Longitudinal Study of Risk Factors Predisposing to Antiretroviral Induced Painful Neuropathy. Ph.D. Thesis, Department of Medicine, Faculty of Health Sciences, University of Cape Town, South Africa.

[7] Boulle, A., Orrel, C., Kaplan, R., et al. (2007) Substitutions Due to Antiretroviral Toxicity or Contraindication in the First 3 Years of Antiretroviral Therapy in a Large South African Cohort. Antiviral Therapy, 12, 753-760.

[8] Ellis, R.J., Rosario, D., Clifford, D.B., et al. (2010) Continued High Prevalence and Adverse Clinical Impact of Human Immuno-Deficiency Virus-Associated Sensory 
Neuropathy in the Era of Combination Antiretroviral Therapy: The Chapter Study. Archives of Neurology, 67, 552-558. https://doi.org/10.1001/archneurol.2010.76

[9] Moyle, G.J. and Sadler, M. (1998) Polyneuropathy with Nucleoside Antiretroviral: Risk Factors, Incidence and Management. Drug Safety, 19, 481-494.

https://doi.org/10.2165/00002018-199819060-00005

[10] Barohn, R.J., Gronseth, G.S., Leforce, B.R., et al. (1993) Peripheral Nervous System Involvement in a Large Cohort of Human Immunodeficiency Virus-Infected Individuals. Archives of Neurology, 50, 167-171.

https://doi.org/10.1001/archneur.1993.00540020045016

[11] So, Y.T., Holtzman, D.M., Abrams, D.I. and Olney, R.K. (1988) Peripheral Neuropathy Associated with Acquired Immunodeficiency Syndrome. Prevalence and Clinical Features from a Population-Based Survey. Archives of Neurology, 45, 945994. https://doi.org/10.1001/archneur.1988.00520330023005

[12] Mehta, S.A., Ahmed, A., Laverty, M., Holzman, R.S., Valentine, F. and Sivapalasingam, S. (2011) Sex Differences in the Incidence of Peripheral Neuropathy among Kenyans Initiating Antiretroviral Therapy. Clinical Infectious Diseases, 53, 490-496. https://doi.org/10.1093/cid/cir432

[13] Mullin, S., Temu, A., Kalluvya, S., Grant, A. and Manji, H. (2011) High Prevalence of Distal Sensory Polyneuropathy in Antiretroviral-Treated and Untreated People with HIV in Tanzania. Tropical Medicine \& International Health, 16, 1291-1296. https://doi.org/10.1111/j.1365-3156.2011.02825.x

[14] Shurie, J.S. and Deribew, A. (2010) Assessment of the Prevalence of Distal Symmetrical Polyneuropathy and Its Risk Factors among HAART-Treated and Untreated HIV Infected Individuals. Ethiopian Medical Journal, 48, 85-93.

[15] Phillips, T.J.C., Cherry, C.L., Moss, P.J. and Rice, A.S.C. (2010) Painful HIV-Associated Sensory Neuropathy. Pain: Clinical Updates, 18, 1-8.

[16] Bygrave, H., Ford, N., Van Cutsem, G., et al. (2011) Implementing a TenofovirBased First-Line Regimen in Rural Lesotho: Clinical Outcomes and Toxicities after Two Years. Journal of Acquired Immune Deficiency Syndromes, 56, e75-e78. https://doi.org/10.1097/QAI.0b013e3182097505

[17] Hung, C.F., Gibson, S.A., Letendre, S.L., et al. (2008) Impact of Long-Term Treatment with Neurotoxic Dideoxynucleoside Antiretrovirals: Implications for Clinical Care In Resource-Limited Settings. HIV Medicine, 9, 731-737. https://doi.org/10.1111/j.1468-1293.2008.00615.x

[18] Pasupthi, P., Ramachandran, T., Sindhu, P.J., Saravanan, G. and Bakthavathsalam, G. (2009) Enhanced Oxidative Stress Markers and Antioxidant Imbalance in HIV Infection and AIDS Patients. Journal of Scientific Research, 1, 370-380. https://doi.org/10.3329/jsr.v1i2.2295

[19] Coaccioli, S., Grapa, G., Fantera, M., et al. (2010) Oxidant/Antioxidant Status in Patients with Chronic HIV Infection. Clinical Therapeutics, 161, 55-58.

[20] Awodele, O., Olayemi, S.O., Nwite, J.A. and Adeyemo, T.A. (2012) Investigation of the Levels of Oxidative Stress Parameters in HIV and HIV-TB Co-Infected Patients. Journal of Infection in Developing Countries, 6, 79-85. https://doi.org/10.3855/jidc.1906

[21] Gil del Valle, L., Hernández, R.G. and Avila, J.P. (2013) Oxidative Stress Associated to Disease Progression and Toxicity during Antiretroviral Therapy in Human Immunodeficiency Virus Infection. Journal of Virology and Microbiology, 1-15. https://doi.org/10.5171/2013.279685

[22] Winter, H. (1996) Gastrointestinal Tract Function and Malnutrition in HIV- 
Infected Children. Journal of Nutrition, 126, 2620S-2622S.

[23] Shevitz, A.H. and Knox, T.A. (2001) Nutrition in the Era of Highly Active Antiretroviral Therapy. Clinical Infectious Diseases, 32, 1769-1775.

https://doi.org/10.1086/320761

[24] Miller, T.L. (2003) Nutritional Aspects of HIV-Infected Children Receiving Highly Active Antiretroviral Therapy. AIDS, 17, S130-S140.

[25] Van Lettow, M., Fawzi, W.W. and Semba, R.D. (2003) Triple Trouble: The Role of Malnutrition in Tuberculosis and Human Immunodeficiency Virus Co-Infection. Nutrition Reviews, 61, 81-90. https://doi.org/10.1301/nr.2003.marr.81-90

[26] Kumar, N. (2007) Nutritional Neuropathies. Neurologic Clinics, 25, 209-255. https://doi.org/10.1016/j.ncl.2006.11.001

[27] Tang, A.M., Graham, N.M., Semba, R.D., et al. (1997) Association between Serum Vitamin A and E Levels and HIV-1 Disease Progression. AIDS, 11, 613-620. https://doi.org/10.1097/00002030-199705000-00009

[28] Kanter, A.S., Spencer, D.C., Steinberg, M.H., et al. (1999) Supplemental Vitamin B and Progression to AIDS and Death in Black South African Patients Infected with HIV. Journal of Acquired Immune Deficiency Syndromes, 21, 252-253. https://doi.org/10.1097/00126334-199907010-00011

[29] Faintuch, J., Soeters, P.B. and Osmo, H.G. (2006) Nutritional and Metabolic Abnormalities in Pre-AIDS HIV Infection. Nutrition, 22, 683-690. https://doi.org/10.1016/j.nut.2006.03.011

[30] WHO (2003) Nutrient Requirements for People Living with HIV/AIDS. Report of a Technical Consultation, WHO, Geneva.

[31] Isanaka, S., Mugusi, F. and Hawkins, C. (2012) Effect of High-Dose vs StandardDose Multivitamin Supplementation at the Initiation of HAART on HIV Disease Progression and Mortality in Tanzania: A Randomized Controlled Trial. JAMA, 308, 1535-1544. https://doi.org/10.1001/jama.2012.13083

[32] Ames, B.N. (2004) Delaying the Mitochondrial Decay of Aging. Annals of the New York Academy of Sciences, 1019, 406-411. https://doi.org/10.1196/annals.1297.073

[33] Arendt, B.M., Aghdassi, E., Mohammed, S.S., et al. (2008) Dietary Intake and Physical Activity in a Canadian Population Sample of Male Patients with HIV Infection and Metabolic Abnormalities. Current HIV Research, 6, 82-90. https://doi.org/10.2174/157016208783571973

[34] Depeint, F., Bruce, W.R., Shangari, N., Mehta, R. and O’Brien, P.J. (2006) Mitochondrial Function and Toxicity: Role of the B Vitamin Family on Mitochondrial Energy Metabolism. Chemico-Biological Interactions, 163, 94-112. https://doi.org/10.1016/j.cbi.2006.04.014

[35] Thompson, J. (2007) Vitamins, Minerals and Supplements. 7: Minerals. Community Practitioner, 80, 38-40.

[36] Dreyfuss, M.L. and Fawzi, W.W. (2002) Micronutrients and Vertical Transmission of HIV-1. The American Journal of Clinical Nutrition, 75, 959-970.

[37] Drain, P.K., Kupka, R., Mugusi, F. and Fawzi, W.W. (2007) Micronutrients in HIV-Positive Persons Receiving Highly Active Antiretroviral Therapy. The American Journal of Clinical Nutrition, 85, 333-345.

[38] Singhal, N. and Austin, J.A. (2002) A Clinical Review of Micronutrients in HIV Infection. Journal of the International Association of Physicians in AIDS Care, 1, 63-75. https://doi.org/10.1177/154510970200100205

[39] Richard, N.P. (1999) Nutrition Science News, Thiamine's Mood-Mending Qualities. http://www.onlineholistichealth.com/resources 
[40] Higdon, J. (2000) Thiamin. Micronutrient Information Center, Oregon State University, USA. http://lpi.oregonstate.edu/infocenter/minerals

[41] Butterworth, R.F. (2006) Thiamin. In: Shils, M.E., Shike, M., Ross, A.C., Caballero, B. and Cousins, R.J., Eds., Modern Nutrition in Health and Disease, 10th Edition, Lippincott Williams \& Wilkins, Baltimore.

[42] Spinazzi, M., Angelini, C. and Patrini, C. (2010) Subacute Sensory Ataxia and Optic Neuropathy with Thiamine Deficiency. Nature Reviews Neuroscience, 6, 288-293. https://doi.org/10.1038/nrneurol.2010.16

[43] Hammond, N., Wang, Y., Dimachkie, M. and Barohn, R. (2013) Nutritional Neuropathies. Neurologic Clinics, 31, 477-489. https://doi.org/10.1016/j.ncl.2013.02.002

[44] Renwick, A.G. (2006) Toxicology of Micronutrients: Adverse Effects and Uncertainty. Journal of Nutrition, 136, 493S-501S.

[45] Lyn Patrick, N.D. (2000) Nutrients and HIV: Part 2-Vitamins A and E, Zinc, B-Vitamins, and Magnesium. Alternative Medicine Review, 5, 39-51.

[46] Aggarwal, B.B., Sundaram, C., Prasad, S. and Kannappan, R. (2010) Tocotrienols, the Vitamin E of the 21st Century: Its Potential against Cancer and Other Chronic Diseases. Biochemical Pharmacology, 80, 1613-1631.

https://doi.org/10.1016/j.bcp.2010.07.043

[47] Panel on Dietary Antioxidants and Related Compounds, Subcommittees on Upper Reference Levels of Nutrients and Interpretation and Uses of DRIs, Standing Committee on the Scientific Evaluation of Dietary Reference Intakes, et al. (2000) Dietary Reference Intakes for Vitamin C, Vitamin E, Selenium, and Carotenoids. Institute of Medicine, The National Academies Press.

[48] Meydani, S., Wu, D., Santos, M. and Hayek, M. (1995) Antioxidants and Immune Response in the Aged: Overview of Present Evidence. The American Journal of Clinical Nutrition, 62, 1462S-1476S.

[49] USAID (2000) HIV/AIDS and Nutrition. A Review of the Literature and Recommendations for Nutritional Care and Support in Sub-Saharan Africa.

[50] Tanphaichitr, V. (1999) Thiamin. In: Shils, M.E., Olsen, J.A. and Shike, M., et al., Eds., Modern Nutrition in Health and Disease, 9th Edition, Lippincott Williams \& Wilkins, Baltimore.

[51] So, Y.T.S. and Roger, P. (2008) Deficiency Diseases of the Nervous System. In: Bradley, W.B., Daroff, R.B., Fenichel, G.M. and Jankovic, J., Eds., Neurology in Clinical Practice, Butterworth-Heinemann, Oxford, 1643-1656.

[52] Gdynia, H.J., Muueller, T., Sperfeld, A.D., et al. (2008) Severe Sensorimotor Neuropathy after Intake of Highest Dosages of Vitamin B6. Neuromuscular Disorders, 18, 156-158.

[53] Simpson, J.L., Bailey, L.B., Pietrzik, K., Shane, B. and Holzgreve, W. (2010) Micronutrients and Women of Reproductive Potential: Required Dietary Intake and Consequences of Dietary Deficiency or Excess. Part I-Folate, Vitamin B12, Vitamin B6. The Journal of Maternal-Fetal \& Neonatal Medicine, 23, 1323-1343. https://doi.org/10.3109/14767051003678234

[54] Leishear, K., Boudreau, R.M., Studenski, S.A., et al. (2012) Relationship between Vitamin B12 and Sensory and Motor Peripheral Nerve Function in Older Adults. Journal of the American Geriatrics Society, 60, 1057-1063. https://doi.org/10.1111/j.1532-5415.2012.03998.x

[55] Vitamin, E. (2009) Review of Natural Products. Facts \& Comparisons 4.0. Wolters Kluwer Health, Inc., St. Louis, MO.

[56] Visser, M.E., Maartens, G., Kossew, G. and Hussey, G.D. (2003) Plasma Vitamin 
and Zinc Concentrations in HIV-Infected Adults in Cape Town, South Africa. British Journal of Nutrition, 89, 475-482. https://doi.org/10.1079/BJN2002806

[57] Beisel, W.R. (1996) Nutrition in Paediatric HIV Infection: Setting the Research Agenda. Nutrition and Immune Function: Overview. Journal of Nutrition, 126, 2611S-2615S.

[58] The Italian Paediatric Intestinal/HIV Study Group (1993) Intestinal Malabsorption of HIV-Infected Children: Relationship to Diarrhoea, Failure to Thrive, Enteric Micro-Organisms and Immune Impairment. The Italian Paediatric Intestinal/HIV Study Group. AIDS, 7, 1435-1440. https://doi.org/10.1097/00002030-199311000-00005

[59] Semba, R.D. and Tang, A.M. (1999) Micronutrients and the Pathogenesis of Human Immunodeficiency Virus Infection. British Journal of Nutrition, 81, 181-189. https://doi.org/10.1017/S0007114599000379

[60] Henderson, R.A., Talusan, K., Hutton, N., Yolken, R.H. and Caballero, B. (1999) Whole Body Protein Turnover in Children with Human Immunodeficiency Virus (HIV) Infection. Nutrition, 15, 189-194. https://doi.org/10.1016/S0899-9007(98)00178-6

[61] Campa, A., Shor-Posner, G., Indacochea, F., et al. (1999) Mortality Risk in Selenium-Deficient HIV-Positive Children. Journal of Acquired Immune Deficiency Syndromes, 20, 508-513.

[62] Srinivas, A. and Dias, B.F. (2008) Antioxidants in HIV Positive Children. Indian Journal of Pediatrics, 75, 347-350. https://doi.org/10.1007/s12098-008-0036-3

[63] Semba, R.D., Shah, N., Strathdee, S.A. and Vlahov, D. (2002) High Prevalence of Iron Deficiency and Anaemia among Female Injection Drug Users with and without HIV Infection. Journal of Acquired Immune Deficiency Syndromes, 29, 142144.

[64] Cos, P., Maes, L., Berghe, D.V., Hermans, N., Pieters, L. and Vlietinck, A. (2004) Plant Substances as Anti-HIV Agents Selected According to Their Putative Mechanism of Action. Journal of Natural Products, 167, 284-293. https://doi.org/10.1021/np034016p

[65] Anabwani, G. and Navario, P. (2005) Nutrition and HIV/AIDS in Sub-Saharan Africa: An Overview. Nutrition, 21, 96-99. https://doi.org/10.1016/j.nut.2004.09.013

[66] Safadi, Y.E., Vivet-Boudou, V. and Marquet, R. (2007) HIV-1 Reverse Transcriptase Inhibitors. Applied Microbiology and Biotechnology, 75, 723-737. https://doi.org/10.1007/s00253-007-0919-7

[67] Cote, H.C., Brumme, Z.L., Craib, K.J., et al. (2002) Changes in Mitochondrial DNA as a Marker of Nucleoside Toxicity in HIV Patients. The New England Journal of Medicine, 346, 811-820. https://doi.org/10.1056/NEJMoa012035

[68] Drain, P.K., Kupka, R., Mugusi, F. and Fawzi, W.W. (2007) Micronutrients in HIV-Positive Persons Receiving Highly Active Antiretroviral Therapy. The American Journal of Clinical Nutrition, 85, 333-345.

[69] De Clercq, E. (2009) The History of Antiretrovirals: Key Discoveries over the Past 25 Years. Reviews in Medical Virology, 19, 287-299. https://doi.org/10.1002/rmv.624

[70] Schramm, C., Wanitschke, R. and Galle, P.R. (1999) Thiamine for the Treatment of Nucleoside Analogue-Induced Severe Lactic Acidosis. European Journal of Anaesthesiology, 16, 733-735. https://doi.org/10.1046/j.1365-2346.1999.00586.x

[71] Fouty, B., Frerman, F. and Reves, R. (1998) Riboflavin to Treat Nucleoside Analogue Induced Lactic Acidosis. The Lancet, 352, 291-292. 
https://doi.org/10.1016/S0140-6736(05)60266-8

[72] Gavrila, A., Sotirios, T., Doweiko, J., et al. (2003) Exercise and Vitamin E Intake Are Independently Associated with Metabolic Abnormalities in Human Immunodeficiency Virus-Positive Subjects: A Cross-Sectional Study. Clinical Infectious Diseases, 36, 1593-1601. https://doi.org/10.1086/375225

[73] Villamor, E., Mugusi, F., Urassa, W., et al. (2008) A Trial of the Effect of Micronutrient Supplementation on Treatment Outcome, T Cell Counts, Morbidity, and Mortality in Adults with Pulmonary Tuberculosis. The Journal of Infectious Diseases, 197, 1499-1505. https://doi.org/10.1086/587846

[74] Lehmann, H.C., Chen, W., Borzan, J., Mankowski, J.L. and Hoke, A. (2011) Mitochondrial Dysfunction in Distal Axons Contributes to Human Immunodeficiency Virus Sensory Neuropathy. Annals of Neurology, 69, 100-110. https://doi.org/10.1002/ana.22150

[75] Hulgan, T., Haas, D.W., Haines, J.L., et al. (2005) Mitochondrial Haplogroups and Peripheral Neuropathy during Antiretroviral Therapy: An Adult AIDS Clinical Trials Group Study. AIDS, 19, 1341-1349. https://doi.org/10.1097/01.aids.0000180786.02930.a1

[76] Canter, J.A., Robbins, G.K. and Selph, D. (2010) African Mitochondrial DNA Subhaplogroups and Peripheral Neuropathy during Antiretroviral Therapy. The Journal of Infectious Diseases, 201, 1703-1707. https://doi.org/10.1086/652419

[77] Tanaka, T., Scheet, P., Giusti, B., et al. (2009) Genome-Wide Association Study of Vitamin B6, Vitamin B12, Folate, and Homo-Cysteine Blood Concentrations. The American Journal of Human Genetics, 84, 477-482. https://doi.org/10.1016/j.ajhg.2009.02.011

[78] Frosst, P., Blom, H.J., Milos, R., et al. (1995) A Candidate Genetic Risk Factor for Vascular Disease: A Common Mutation in Methylenetetrahydrofolate Reductase. Nature Genetics, 10, 111-113. https://doi.org/10.1038/ng0595-111

[79] Klerk, M., Verhoef, P., Clarke, R., Blom, H.J., Kok, F.J. and Schouten, E.G. (2002) $M T H F R$ 677C $\rightarrow \mathrm{T}$ Polymorphism and Risk of Coronary Heart Disease: A Meta-Analysis. JAMA, 288, 2023-2031. https://doi.org/10.1001/jama.288.16.2023

[80] McCully, K.S. (2007) Homocysteine, Vitamins, and Vascular Disease Prevention. The American Journal of Clinical Nutrition, 86, 1563S-1568S.

[81] Fredriksen, A., Meyer, K., Ueland, P.M., Vollset, S.E., Grotmol, T. and Schneede, J. (2007) Large-Scale Population-Based Metabolic Phenotyping of Thirteen Genetic Polymorphisms Related to One-Carbon Metabolism. Human Mutation, 28, 856865. https://doi.org/10.1002/humu.20522

[82] Mornet, E. (2000) Hypophosphatasia: The Mutations in the Tissue-Nonspecific Alkaline Phosphatase Gene. Human Mutation, 15, 309-315. https://doi.org/10.1002/(SICI)1098-1004(200004)15:4<309::AID-HUMU2>3.0.CO;2 $-\mathrm{C}$

[83] Yuan, X., Waterworth, D., Perry, J.R., et al. (2008) Population-Based Genome-Wide Association Studies Reveal Six Loci Influencing Plasma Levels of Liver Enzymes. American Journal of Human Genetics, 83, 520-528. https://doi.org/10.1016/j.ajhg.2008.09.012

[84] Kaptan, K., Beyan, C., Ural, A.U., et al. (2000) Helicobacter pylori-Is It a Novel Causative Agent in Vitamin B12 Deficiency? Archives of Internal Medicine, 160, 1349-1353.

[85] Kelly, R.J., Rouquier, S., Giorgi, D., Lennon, G.G. and Lowe, J.B. (1995) Sequence and Expression of a Candidate for the Human Secretor Blood Group $\alpha(1,2)$ Fuco- 
syltransferase Gene (FUT2). Homozygosity for an Enzyme-Inactivating Nonsense Mutation Commonly Correlates with the Non-Secretor Phenotype. Journal of Biological Chemistry, 270, 4640-4649. https://doi.org/10.1074/jbc.270.9.4640

[86] Hazra, A., Kraft, P., Selhub, J., et al. (2008) Common Variants of FUT2 Are Associated with Plasma Vitamin B12 Levels. Nature Genetics, 40, 1160-1162. https://doi.org/10.1038/ng.210

[87] Serpa, J., Mendes, N., Reis, C.A., et al. (2004) Two New FUT2 (Fucosyltransferase 2 Gene) Missense Polymorphisms, 739G $\rightarrow$ A and 839T $\rightarrow$ C, Are Partly Responsible for Non-Secretor Status in a Caucasian Population from Northern Portugal. Biochemical Journal, 383, 469-474. https://doi.org/10.1042/BJ20040803

[88] Tanner, S.M., Li, Z., Perko, J.D., et al. (2005) Hereditary Juvenile Cobalamin Deficiency Caused by Mutations in the Intrinsic Factor Gene. Proceedings of the National Academy of Sciences of the United States of America, 102, 4130-4133. https://doi.org/10.1073/pnas.0500517102

[89] Tanner, S.M., Li, Z., Bisson, R., et al. (2004) Genetically Heterogeneous Selective Intestinal Malabsorption of Vitamin B12: Founder Effects, Consanguinity, and High Clinical Awareness Explain Aggregations in Scandinavia and the Middle East. $\mathrm{Hu}$ man Mutation, 23, 327-333. https://doi.org/10.1002/humu.20014

[90] Belisle, S.E., Leka, L.S., Delgado-Lista, J., Jacques, P.F., Ordovas, J.M. and Meydani, S.N. (2009) Polymorphisms at Cytokine Genes May Determine the Effect of Vitamin E on Cytokine Production in the Elderly. Journal of Nutrition, 139, 1855-1860. https://doi.org/10.3945/jn.109.112268

[91] Major, J.M., Yu, K., Chung, C.C., et al. (2012) Genome-Wide Association Study Identifies Three Common Variants Associated with Serologic Response to Vitamin E Supplementation in Men. Journal of Nutrition, 142, 866-871. https://doi.org/10.3945/jn.111.156349

\section{Submit or recommend next manuscript to SCIRP and we will provide best service for you:}

Accepting pre-submission inquiries through Email, Facebook, LinkedIn, Twitter, etc. A wide selection of journals (inclusive of 9 subjects, more than 200 journals) Providing 24-hour high-quality service User-friendly online submission system Fair and swift peer-review system Efficient typesetting and proofreading procedure Display of the result of downloads and visits, as well as the number of cited articles Maximum dissemination of your research work

Submit your manuscript at: http://papersubmission.scirp.org/

Or contactwwa@scirp.org 